\title{
Karakteristik Muatan dan Sifat Fisikokimia Tanah pada Ultisol dan Andisol di Lahan Kering Aceh Besar
}

\author{
(Characteristics of Charge and Soil Physicochemical Properties of Ultisol and \\ Andisol in Dry land of Aceh Besar)
}

\author{
Mulkan Kautsar ${ }^{1}$, Ilyas $^{1}$, Sufardi $^{1 *}$ \\ ${ }^{1}$ Program Studi Ilmu Tanah, Fakultas Pertanian, Universitas Syiah Kuala
}

\begin{abstract}
Abstrak. Penelitian ini bertujuan untuk mengkaji karakteristik muatan dan sifat fisikokimia tanah pada Ultisol dan Andisol di lahan kering di Aceh Besar dengan menggunakan metode deskriptif pada jenis tanah Ultisol yang berasal dari Jantho dan Andisol dari Saree. Parameter yang di analisis yaitu kadar air, tekstur, pH, kapasitas tukar kation (KTK), kation dapat dipertukarkan (Ca-dd, Mg-dd, K-dd, Na-dd), kejenuhan basa, kapasitas tukar anion (KTA), C-organik, kemasaman dapat dipertukarkan ( $\mathrm{Al}$ dan $\mathrm{H}$ ), $\mathrm{pH}_{0}, \mathrm{P}$-retensi dan $\mathrm{pH} \mathrm{NaF}$. Hasil penelitian menunjukan bahwa Ultisol dan Andisol di lahan kering Aceh Besar termasuk kedalam liat aktifitas rendah (LAR) yang ditandai dengan KTK efektif $<12 \mathrm{cmol} \mathrm{kg}^{-1}$. Karakteristik muatan pada Ultisol Jantho dan Andisol Saree mempunyai muatan neto negatif dan bermuatan variabel. Penurunan C-organik dengan bertambahnya kedalaman tanah pada Ultisol dan Andisol diikuti oleh penurunan $\mathrm{pH}_{0}$, P-retensi, dan Al-dd. Upaya untuk meningkatkan muatan negatif pada Ultisol dan Andisol yaitu dengan meningkatkan $\mathrm{pH}$ atau menurunkan muatan titik nol tanah melalui pemberian bahan organik atau bahan yang mempunyai $\mathrm{pH}_{0}$ yang rendah seperti kompos, terak baja, batuan fosfat, bokashi sekam padi, dan abu terbang batubara.
\end{abstract}

Kata kunci: Karakteristik, Muatan, Fisikokimia, Ultisol, Andisol

Abstract. This study aims to examine the characteristics of charge and physicochemical properties of Ultisol and Andisol in dry land of Aceh Besar using descriptive methods in Ultisol from Jantho and Andisol from Saree. Parameters analyzed are water content, texture, $\mathrm{pH}$, cation exchange capacity (CEC), exchangeable cations $(\mathrm{Ca}-$ dd, Mg-dd, K-dd, Na-dd), base saturation, anion exchange capacity (AEC), C-organic, acidity exchangeable (Al and $\mathrm{H}$ ), $\mathrm{pH}_{0}, \mathrm{P}$-retention and $\mathrm{NaF} \mathrm{pH}$. The results showed that Ultisol and Andisol in dry land of Aceh Besar included in the low activity clay (LAC) characterized by effective CEC $12<\mathrm{kg}-1$. Characteristics of charge in Ultisol Jantho and Andisol Saree have a negative charge and variable charge. Decrease in C-organic by increasing the depth of soil in Ultisol and Andisol followed by decreased $\mathrm{pH}_{0}, \mathrm{P}$-retention, and Al-dd. Efforts to increase the negative charge on Ultisol and Andisol by increasing the $\mathrm{pH}$ or decreasing the zero point of charge of the soil through giving of organic matter or materials that have a low $\mathrm{pH}_{0}$ such as compost, steel slag, rock phosphate, Bokashi rice husk and coal fly ash.

Keyword: Characteristics, charge, physicochemical, Ultisol, Andisol

\section{PENDAHULUAN}

Sebagian besar tanah-tanah di wilayah iklim tropika basah bermuatan variabel ordo Oxisol, Ultisol, Alfisol, Spodosol dan Andisol merupakan tanah bermuatan variabel. Tanah tersebut cukup banyak terdapat di muka bumi, dan merupakan tanah yang telah melapuk sangat lanjut atau tanah berkembang dari abu gunung api (Theng, 1980).

Ultisol merupakan salah satu kelompok tanah yang bermuatan variabel (Ali dan Sufardi, 1999). Ultisol mempunyai potensi keracunan Al, miskin kandungan bahan organik dan kandungan hara terutama $\mathrm{P}$ dan kation-kation dapat tertukar lainnya seperti $\mathrm{Ca}, \mathrm{Mg}, \mathrm{Na}$ dan K, kapasitas tukar kation (KTK) rendah, serta peka terhadap erosi (Sudaryono, 2009). Selain itu Ultisol juga mempunyai liat beraktivitas rendah yang ditandai dengan rendahnya kemampuan koloid tanah dalam meretensi kation, sehingga kapasitas kation menjadi rendah (Sanchez, 1992).

Selain Ultisol, Andisol juga merupakan tanah dengan muatan variabel. Permasalahan pada Andisol yang paling umum adalah sebagian besar fosfat terikat oleh mineral alofan tanah 
sehingga $\mathrm{P}$ tidak tersedia bagi tanaman (Sembiring et al., 2013). Andisol juga dicirikan dengan nilai muatan titik nol (Zero point of charge) yang tinggi (Uehara dan Gillman, 1981).

Kabupaten Aceh Besar memiliki lahan kering seluas 89.134,34 hektar yang terbentuk atas beberapa jenis tanah seperti Podsolik, Kambisol, Aluvial, Litosol, Andosol, dan Renzina (Sufardi et al., 2017). Ditinjau dari aspek fisikokimia, rendahnya kualitas tanah tersebut berhubungan erat dengan karakteristik muatan pada permukaan koloid. Pada tanah dengan sistem muatan variabel, besarnya muatan negatif dipengaruhi oleh potensial permukaan $(\mathrm{pH}-$ $\mathrm{pH}_{0}$ ), konsentrasi elektrolit, valensi ion, konstanta larutan, dan temperatur (Uehara dan Gillman, 1981).

Saat ini usaha pengelolaan untuk mengatasi permasalahan pada Ultisol dan Andisol telah dilakukan secara meluas namun masih terbatas pada parameter-parameter kesuburan secara umum, sedangkan analisis sifat kimia yang berhubungan dengan sistem muatan tanah dan dinamika hara dalam tanah dan tanaman masih terabaikan. Padahal parameter ini merupakan sifat hakiki tanah karena dapat digunakan sebagai dasar dalam pengelolaan tanah.

\section{METODE PENELITIAN}

\section{Tempat dan Waktu Penelitian}

Penelitian ini dilakukan di Kabupaten Aceh Besar pada lokasi yang terdapat tanah ordo Ultisol dan Andisol untuk selanjutnya dilakukan analisis di Laboratorium Kimia Tanah Fakultas Pertanian Universitas Syiah Kuala Banda Aceh. Penelitian ini dilaksanakan pada bulan Agustus - November 2017.

\section{MATERI DAN METODE}

\section{Bahan dan Alat}

Bahan-bahan yang digunakan dalam penelitian ini terdiri dari: sampel tanah pada tiaptiap horizon dari 2 profil, masing-masing 1 profil tanah ordo Ultisol dari Jantho dan Andisol dari Saree serta bahan-bahan kimia di laboratorium. Alat-alat yang digunakan dalam penelitian ini berupa peta jenis tanah, bor tanah, cangkul, GPS, abney level, buku Munsell colour chart, $\mathrm{pH}$ tancap, kantung plastik, meteran, pisau, daftar isian profil tanah, alat tulis serta peralatan analisis tanah di laboratorium.

\section{Metode Penelitian}

Penelitian ini menggunakan metode deskriptif yang diawali dengan pengamatan berdasarkan peta jenis tanah yang berguna untuk menentukan lokasi pengambilan sampel tanah dari jenis tanah yang akan di teliti. Selanjutnya pengecekan ke lapangan berdasarkan titik terpilih dengan jalan pemboran tanah sampai kedalaman $100 \mathrm{~cm}$. Setelah itu dilakukan pembuatan profil untuk diamati sifat-sifat morfologi dan pengambilan sampel tanah.

\section{Pengamatan Lapangan dan Analisis Sampel}

Pengamatan lapangan dilakukan secara fisik untuk mengetahui keadaan lahan di lokasi penelitian. Pada tahap ini mencakup kegiatan pemilihan lokasi, pembuatan dan deskripsi profil serta pengambilan contoh tanah. Pemilihan lokasi didasarkan pada hasil orientasi dengan penjelajahan wilayah. Sifat-sifat tanah yang di analisis mencakup sifat fisika dan kimia dengan parameter yang dianalisis disesuaikan dengan tujuan penelitian. Setelah semua data di lapangan didapatkan maka dilanjutkan dengan analisis di laboratorium yang mencakup beberapa sifat tanah, antara lain: 


\begin{tabular}{|c|c|}
\hline Sifat fisikokimia & Metode \\
\hline Kadar Air (KA) & Gravimetri \\
\hline Tekstur & Pipet \\
\hline $\mathrm{pH}\left(\mathrm{H}_{2} \mathrm{O}\right.$ dan $\left.\mathrm{KCl}\right)$ & Elektrometrik \\
\hline KTK & $1 \mathrm{~N} \mathrm{NH}_{4} \mathrm{OAC} \mathrm{pH} 7$ \\
\hline Kation Basa dapat ditukar $(\mathrm{Ca}, \mathrm{Mg}, \mathrm{K}, \mathrm{Na})$ & $1 \mathrm{~N} \mathrm{NH}_{4} \mathrm{OAC} \mathrm{pH} 7$ \\
\hline $\mathrm{KB}$ & $\frac{\mathrm{Ca}+\mathrm{Mg}+\mathrm{K}+\mathrm{Na}}{\mathrm{KTK}} \times 100 \%$ \\
\hline KTA & Prosedur SNI \\
\hline C-organik & Walkley and Black \\
\hline Al-dd dan H-dd & $1 \mathrm{~N} \mathrm{KCl}$ \\
\hline $\mathrm{pH}_{0}$ & Uehara Gillman \\
\hline Retensi P & Blakemore \\
\hline $\mathrm{pH} \mathrm{NaF}$ & Elektrometrik \\
\hline
\end{tabular}

\section{HASIL DAN PEMBAHASAN}

\section{Sifat-Sifat Muatan}

Dari hasil penelitian diketahui bahwa $\mathrm{pH} \mathrm{H}_{2} \mathrm{O}$ Ultisol dan Andisol memperlihatkan nilai yang bervariasi dari agak masam sampai netral. $\mathrm{pH} \mathrm{H}_{2} \mathrm{O}$ Ultisol berkisar antara 6,16-6,73 dengan $\mathrm{pH} \mathrm{KCl} \mathrm{4,88-5,60,} \mathrm{sedangkan} \mathrm{pH} \mathrm{H}_{2} \mathrm{O}$ Andisol berkisar antara 5,52-6,57 dan $\mathrm{pH} \mathrm{KCl}$ yaitu 4,62-5,37 (Tabel 1).

Tabel 1. Nilai $\mathrm{pH} \mathrm{H}_{2} \mathrm{O}, \mathrm{pH} \mathrm{KCl}, \Delta \mathrm{pH}, \mathrm{pH}_{0}, \mathrm{pH}_{0}-\mathrm{pH} \mathrm{H}_{2} \mathrm{O}$ Ultisol dan Andisol

\begin{tabular}{ccccccc}
\hline Ordo Tanah & Horizon & \multicolumn{3}{c}{$\mathrm{pH}$} & & \multicolumn{2}{c}{} & $\mathrm{pH}_{0}$ & $\mathrm{pH}_{0}-\mathrm{pH} \mathrm{H}_{2} \mathrm{O}$ \\
\cline { 2 - 4 } & & $\mathrm{H}_{2} \mathrm{O}$ & $\mathrm{KCl}$ & & & \\
\hline \multirow{3}{*}{ Ultisol } & $\mathrm{O}$ & 6,36 & 5,12 & $-1,24$ & 4,89 & $-1,47$ \\
& $\mathrm{~A}$ & 6,16 & 4,88 & $-1,28$ & 5,42 & $-0,74$ \\
& $\mathrm{Bt}_{1}$ & 6,58 & 5,21 & $-1,37$ & 5,60 & $-0,98$ \\
& $\mathrm{Bt}_{2}$ & 6,73 & 5,60 & $-1,13$ & 6,71 & $-0,02$ \\
\hline \multirow{3}{*}{ Andisol } & $\mathrm{O}$ & 5,62 & 4,86 & $-0,76$ & 5,35 & $-0,27$ \\
& $\mathrm{~A}$ & 5,52 & 4,62 & $-0,90$ & 3,06 & $-2,46$ \\
& $\mathrm{AB}$ & 6,51 & 5,33 & $-1,18$ & 5,12 & $-1,39$ \\
& $\mathrm{~B}$ & 6,57 & 5,37 & $-1,20$ & 6,08 & $-0,49$ \\
\hline
\end{tabular}

Pada Tabel 1 menunjukan bahwa pH Ultisol dan Andisol meningkat dengan semakin bertambahnya kedalaman tanah. $\mathrm{pH}$ tanah dapat dipengaruhi oleh beberapa faktor, antara lain bahan induk tanah, bahan organik, hidrolisis aluminium, reaksi oksidasi terhadap mineral tertentu dan pencucian basa-basa (Syahputra et al., 2015). Dalam hal ini pencucian basa-basa merupakan penyebab utama kemasaman tanah. $\mathrm{pH}$ tanah juga berhubungan dengan kandungan aluminium dapat dipertukarkan dan kejenuhan aluminium, semakin meningkat nilai $\mathrm{pH}$ tanah maka nilai Al-dd di dalam tanah akan semakin menurun. Begitu juga sebaliknya, dengan menurunnya $\mathrm{pH}$ tanah maka nilai Al-dd di dalam tanah akan semakin meningkat. Hal ini sejalan dengan yang dikemukakan Subandi (2007) bahwa nilai pH tanah yang relatif mudah diukur dapat digunakan untuk panduan dalam menduga tingkat kejenuhan Al.

Besarnya muatan koloid tanah dapat ditentukan dengan mengukur perbedaan $\mathrm{pH} \mathrm{H}_{2} \mathrm{O}$ dengan $\mathrm{pH} \mathrm{KCl}$ yang dinyatakan sebagai $\Delta \mathrm{pH}=\mathrm{pH} \mathrm{KCl-pH} \mathrm{H}_{2} \mathrm{O}$. Artinya yaitu jika $\mathrm{pH} \mathrm{KCl-}$ $\mathrm{pH} \mathrm{H}_{2} \mathrm{O}$ suatu tanah bernilai negatif maka muatannya adalah negatif, sebaliknya apabila $\Delta \mathrm{pH}$ bernilai positif, maka muatan tanahnya yaitu positif. Tanah pada penelitian ini semuanya 
mempunyai $\Delta \mathrm{pH}$ negatif. Apabila $\Delta \mathrm{pH}$ positif, nol atau negatif absolutnya kecil, umumnya menunjukkan tanah-tanah yang bermuatan variabel (Uehara dan Gillman, 1981). Tetapi menurut Arabia (1991), tanah-tanah yang semuanya terdiri dari muatan variabel jarang terjadi pada daerah tropika basah, tanah-tanah ini biasanya mengandung campuran mineral-mineral bermuatan variabel seperti kaolinit, oksida Fe dan Al serta muatan permanen seperti montmorillonit, illit dan vermikulit.

Nilai $\Delta \mathrm{pH}$ pada Ultisol daerah penelitian berkisar antara -1,13 sampai -1,37 dengan nilai terendah pada horizon $\mathrm{Bt}_{2}$ dan tertinggi pada horizon $\mathrm{Bt}_{1}$. Sedangkan nilai dari $\Delta \mathrm{pH}$ Andisol berkisar antara -0,76 sampai -1,20 dengan nilai terendah pada horizon $\mathrm{O}$ dan tertinggi pada horizon B. Nilai $\Delta \mathrm{pH}$ negatif yang besar tidak dapat dikatakan apakah bermuatan permanen atau variabel tetapi menunjukan tingginya kerapatan muatan permukaan negatif.

\section{Muatan Titik Nol}

Ultisol dan Andisol memiliki muatan yang tergantung $\mathrm{pH}$, tanah akan bermuatan positif jika kondisi $\mathrm{pH}$ asam dan akan bermuatan negatif jika $\mathrm{pH}$ yang lebih tinggi. Kondisi ini disebut dengan kondisi tanah yang bermuatan variabel. Kondisi $\mathrm{pH}$ yang demikian merupakan kondisi titik antara muatan positif dan negatif permukaan koloid bernilai nol yang sering disebut sebagai titik muatan pada kondisi nol atau zero point of charge (ZPC). Muatan positif berpengaruh terhadap sifat kimia tanah. Pada saat $\mathrm{pH}$ rendah, tanah memiliki kapasitas yang rendah untuk mengikat kation dan tanah yang demikian dianggap tidak subur.

Muatan titik nol $\left(\mathrm{pH}_{0}\right)$ merupakan parameter yang sangat penting pada sistem muatan tanah karena dapat menentukan tanda muatan neto tanah. Muatan koloid tanah dapat ditentukan dengan selisih $\mathrm{pH}_{0}-\mathrm{pH}$ tanah. Jika $\mathrm{pH}$ tanah lebih rendah dari $\mathrm{pH}_{0}$, maka permukaan tanah bermuatan neto positif. Sebaliknya jika $\mathrm{pH}$ tanah lebih besar daripada $\mathrm{pH}_{0}$ maka permukaan tanah bermuatan neto negatif (Uehara dan Gillman, 1981).

Pada Tabel 1 terlihat bahwa Ultisol dan Andisol pada penelitian ini bermuatan neto negatif. Nilai $\mathrm{pH}_{0}-\mathrm{pH} \mathrm{H}_{2} \mathrm{O}<-0,5$ pada horizon Ultisol maupun Andisol menunjukkan adanya muatan variabel pada kedua jenis tanah tersebut. Nilai $\mathrm{pH}_{0}$ cenderung semakin meningkat dengan semakin bertambahnya kedalaman tanah. Hal ini sesuai dengan pendapat Uehara dan Gillman (1981) yang menyatakan bahwa pada lapisan atas tanah bermuatan variabel mempunyai nilai $\mathrm{pH}_{0}$ yang rendah dibandingkan lapisan bawah karena lapisan atas mempunyai kandungan bahan organik yang lebih tinggi.

Selisih $\mathrm{pH}_{0}-\mathrm{pH} \mathrm{H}_{2} \mathrm{O}$ pada horizon O Ultisol dan horizon A Andisol yang masih besar menunjukan tingkat perkembangannya yang belum lanjut. Hal ini juga disebabkan adanya bahan organik pada permukaan tanah yang mempunyai $\mathrm{pH}_{0}$ rendah sehingga selisih $\mathrm{pH}_{0}-\mathrm{pH}$ $\mathrm{H}_{2} \mathrm{O}$ semakin besar. Sedangkan semakin ke lapisan bawah selisih $\mathrm{pH}_{0}-\mathrm{pH} \mathrm{H}_{2} \mathrm{O}$ semakin kecil menunjukan tanahnya sudah mengalami perkembangan yang lebih lanjut dibandingkan pada lapisan permukaan. Perkembangan suatu tanah tidak hanya dipengaruhi oleh selisih $\mathrm{pH}_{0}-\mathrm{pH}$ $\mathrm{H}_{2} \mathrm{O}$ saja tetapi juga dipengaruhi oleh faktor-faktor lainnya seperti iklim, mineral yang terdapat dalam tanah serta kadar fraksi debu dan liat. Hal ini sesuai dengan hasil penelitian Agus (1987) dalam Devnita (2010) yang menyatakan bahwa semakin lanjut tingkat perkembangan tanah maka rasio antara fraksi debu dan rasio liat akan semakin kecil.

\section{Hubungan Sifat Kimia Tanah dengan Muatan Tanah}

\section{Kapasitas Tukar Kation (KTK)}

Nilai kapasitas tukar kation (KTK) Ultisol dan Andisol pada penelitian ini berkisar antara rendah sampai tinggi. Ultisol dengan nilai $\mathrm{KTK}$ tertinggi terdapat pada $\mathrm{Bt}_{1}$ yaitu 35,02 cmol kg-1 diikuti oleh horizon $\mathrm{Bt}_{2}$, A dan $\mathrm{O}$ dengan masing-masing nilai yaitu: $28,56 \mathrm{cmol} \mathrm{kg}$ 1, 20,88 $\mathrm{cmol} \mathrm{kg}^{-1}$ dan $15,35 \mathrm{cmol} \mathrm{kg}^{-1}$. Sedangkan pada Andisol, KTK tertinggi ditemukan 
pada horizon $\mathrm{O}$ dengan nilai $39,87 \mathrm{cmol} \mathrm{kg}^{-1}$ yang diikuti oleh horizon $\mathrm{A}, \mathrm{AB}$ dan $\mathrm{B}$ dengan masing-masing nilai $35,16 \mathrm{cmol} \mathrm{kg}^{-1}, 24,58 \mathrm{cmol} \mathrm{kg}{ }^{-1}$ dan 7,67 $\mathrm{cmol} \mathrm{kg}^{-1}$ (Tabel 2).

Horizon $\mathrm{Bt}_{1}$ Ultisol dan Horizon $\mathrm{O}$ Andisol mempunyai KTK yang lebih tinggi dibandingkan dengan horizon lainnya pada jenis tanah yang sama karena kandungan liatnya lebih banyak. Kandungan liat yang lebih tinggi ini diamati berdasarkan hasil pengamatan yang menunjukkan tekstur tanah Ultisol berkisar antara liat sampai liat berpasir, sementara Andisol dengan tekstur tanah lempung berdebu sampai lempung berpasir. Hal ini sesuai dengan pernyataan Devnita (2010) bahwa Kandungan liat yang lebih tinggi bersama-sama dengan $\mathrm{pH}$ tanah yang lebih tinggi akan menyebabkan KTK tanah lebih besar.

Tabel 2. Nilai KTK tanah, KTK Efektif, Muatan variabel Ultisol dan Andisol

\begin{tabular}{ccccc}
\hline Ordo Tanah & Horizon & $\begin{array}{c}\text { KTK } \\
\left(\mathrm{cmol} \mathrm{kg}^{-1}\right)\end{array}$ & $\begin{array}{c}\text { KTK Efektif } \\
\left(\mathrm{cmol} \mathrm{kg}^{-1}\right)\end{array}$ & $\begin{array}{c}\text { Muatan variabel } \\
\left(\mathrm{cmol} \mathrm{kg}^{-1}\right)\end{array}$ \\
\hline Ultisol & $\mathrm{O}$ & 15,35 & 3,97 & 11,88 \\
& $\mathrm{~A}$ & 20,88 & 6,05 & 15,54 \\
& $\mathrm{Bt}_{1}$ & 35,02 & 10,26 & 25,28 \\
& $\mathrm{Bt}_{2}$ & 28,56 & 9,65 & 19,22 \\
\hline \multirow{2}{*}{ Andisol } & $\mathrm{O}$ & 39,87 & 11,55 & 29,10 \\
& $\mathrm{~A}$ & 35,16 & 2,86 & 33,74 \\
& $\mathrm{AB}$ & 24,58 & 2,44 & 22,70 \\
& $\mathrm{~B}$ & 7,67 & 2,02 & 6,41 \\
\hline
\end{tabular}

Ultisol dan Andisol daerah penelitian termasuk ke dalam tanah liat aktifitas rendah (LAR), karena mempunyai KTK efektif $<12 \mathrm{cmol} \mathrm{kg}^{-1}$. Dari Tabel 2 terlihat bahwa Ultisol memiliki KTK efektif 3,97-10,26 cmol kg-1, sedangkan Andisol memiliki KTK efektif 2,02$11,55 \mathrm{cmol} \mathrm{kg}^{-1}$. Menurut Arabia (1991), walaupun bahan organik mempunyai daya jerap kation yang lebih besar dibandingkan dengan mineral liat pada LAR, namun sumbangannya terhadap KTK tidak terlalu besar dikarenakan jumlahnya pada tanah tersebut relatif rendah.

Pada tanah LAR, mineral liatnya didominasi oleh mineral kaolinit. Muatan negatifnya yang menyumbang nilai KTK berasal dari: (1) disosiasi hidrogen pada gugus hidroksil $(\mathrm{OH})$ yang diikat oleh Si dan Al pada masing-masing lempeng, (2) muatan yang tidak dipenuhi pada kisi-kisi lempeng yang patah, dan (3) sedikit dari substitusi isomorfik. Efektifitasnya terbatas hanya pada permukaan luar saja, sehingga nilai KTK nya kecil. Sedangkan tanah dengan muatan pemanen didominasi oleh mineral montmorillonit. Muatan negatifnya berasal dari substitusi isomorfik yang mempunyai efektifitas pada permukaan luar dan dalam sehingga mempuyai KTK lebih besar (Arabia, 1991).

KTK juga dapat digunakan dalam menghitung jumlah muatan variabel. Dari Tabel 2 diketahui bahwa jumlah muatan variabel pada Andisol lebih tinggi dibandingkan dengan Ultisol. Jumlah muatan variabel pada Andisol berkisar antara 6,41-33,74 $\mathrm{cmol} \mathrm{kg}^{-1}$ sedangkan pada Ultisol berkisar antara $11,88-25,28 \mathrm{cmol} \mathrm{kg}^{-1}$. Muatan variabel ini muncul diakibatkan oleh fraksi-fraksi tanah tersebut bersifat amfoter sehingga muatan bersih (neto) pada koloid tanah dapat berubah-ubah.

\section{Kation Basa Dapat Ditukar (Ca-dd, Mg-dd, N-dd, dan K-dd)}

Kation basa yang dianalisis yaitu Ca-dd, Mg-dd, K-dd dan Na-dd dimana keempat kation tersebut tergolong utama dalam tanah. Kation $\mathrm{Ca}, \mathrm{Mg}, \mathrm{K}$ dan $\mathrm{Na}$ dapat digunakan dalam penentuan persentase kejenuhan basa. Nilai kation basa yang dapat ditukar pada Ultisol dan Andisol bervariasi pada setiap horizon. Nilai Ca-dd berkisar antara sangat rendah sampai rendah pada kedua jenis tanah. Nilai Mg-dd berkisar antara sangat rendah hingga tinggi. K-dd 
termasuk dalam kriteria sedang sampai sangat tinggi dan Na-dd dengan kriteria rendah. Dari hasil penelitian diketahui jumlah basa-basa dapat dipertukarkan pada Andisol lebih rendah dibandingkan dengan Ultisol yaitu 1,26-10,77 $\mathrm{cmol} \mathrm{kg}^{-1}$, walaupun mempunyai nilai KTK yang lebih tinggi. Hal ini dapat dijelaskan karena kation-kation terdiri dari kation basa $(\mathrm{Ca}$, $\mathrm{Mg}, \mathrm{Na}$, dan $\mathrm{K}$ ) dan kation asam ( $\mathrm{Al}$ dan $\mathrm{H})$.

Tabel 3. Nilai Kation Basa Dapat Ditukar (Ca-dd, Mg-dd, K-dd, Na-dd), Jumlah Kation, Kejenuhan Basa Ultisol dan Andisol

\begin{tabular}{|c|c|c|c|c|c|c|c|}
\hline \multirow{2}{*}{$\begin{array}{l}\text { Ordo } \\
\text { Tanah }\end{array}$} & \multirow[b]{2}{*}{ Horizon } & \multicolumn{4}{|c|}{ Kation Basa dapat ditukar $\left(\mathrm{cmol} \mathrm{kg}^{-1}\right)$} & \multirow{2}{*}{$\begin{array}{l}\sum \text { Kation } \\
\left(\mathrm{cmol} \mathrm{kg}^{-1}\right)\end{array}$} & \multirow[t]{2}{*}{$\mathrm{KB}(\%)$} \\
\hline & & Ca-dd & Mg-dd & K-dd & Na-dd & & \\
\hline \multirow[t]{4}{*}{ Ultisol } & $\mathrm{O}$ & 0,36 & 2,27 & 0,70 & 0,14 & 3,47 & 22,60 \\
\hline & A & 0,40 & 3,15 & 1,66 & 0,13 & 5,34 & 25,57 \\
\hline & $\mathrm{Bt}_{1}$ & 4,41 & 4,45 & 0,75 & 0,13 & 9,74 & 27,81 \\
\hline & $\mathrm{Bt}_{2}$ & 5,67 & 2,81 & 0,75 & 0,11 & 9,34 & 32,70 \\
\hline \multirow[t]{4}{*}{ Andisol } & $\mathrm{O}$ & 3,31 & 5,78 & 1,57 & 0,11 & 10,77 & 27,01 \\
\hline & A & 0,31 & 0,26 & 0,74 & 0,11 & 1,42 & 4,03 \\
\hline & $\mathrm{AB}$ & 0,49 & 0,73 & 0,55 & 0,11 & 1,88 & 7,64 \\
\hline & B & 0,26 & 0,39 & 0,50 & 0,11 & 1,26 & 16,42 \\
\hline
\end{tabular}

\section{Kejenuhan Basa}

Kejenuhan basa pada penelitian ini mempunyai nilai $<35 \%$. Nilai ini dapat digunakan untuk mengklasifikasikan tanah pada ordo Ultisol. Kejenuhan basa pada Ultisol termasuk dalam kriteria rendah sedangkan pada Andisol berkisar antara sangat rendah sampai rendah. Nilai kejenuhan basa berhubungan erat dengan $\mathrm{pH}$, KTK dan tingkat kesuburan tanah. Kemasaman akan menurun dan kesuburan akan meningkat dengan meningkatnya kejenuhan basa. Laju pelepasan kation terjerap bagi tanaman tergantung pada tingkat kejenuhan basa tanah. Kejenuhan basa tanah dikatakan tidak subur jika kurang dari 50\% (Tan, 2010). Pada penelitian ini dapat dilihat bahwa kejenuhan basa Ultisol lebih tinggi dibandingkan Andisol. Kejenuhan basa tertinggi Ultisol ditemui pada horizon $\mathrm{Bt}_{2}$, diikuti horizon $\mathrm{Bt}_{1}$, horizon $\mathrm{A}$ dan horizon $\mathrm{O}$ dengan masing-masing nilainya yaitu: $32,70 \%, 27,81 \%, 25,57 \%$ dan 22,60\%. Sedangkan pada Andisol nilai tertinggi ditemui pada horizon $\mathrm{O}$, diikuti horizon $\mathrm{B}$, horizon $\mathrm{AB}$ dan horizon A dengan masing-masing nilainya yaitu: 27,01\%, 16,42\%, 7,64\% dan 4,03\%.

\section{Kapasitas Tukar Anion (KTA)}

Pada daerah penelitian terlihat bahwa kapasitas tukar anion (KTA) Ultisol semakin tinggi dengan semakin bertambahnya kedalaman tanah sedangkan KTA pada Andisol semakin rendah dengan bertambahnya kedalaman tanah. Seperti yang telah diuraikan sebelumnya bahwa tanah-tanah tersebut sudah menunjukkan adanya muatan variabel, maka tanah tersebut mempunyai Kapasitas Tukar Anion.

Tanah-tanah dengan kapasitas tukar anion tinggi umumnya memiliki polimer hidroksiAl pada permukaan mineral, seperti mineral besi atau alumunium oksida. Kedua mineral tersebut dapat memberikan kontribusi terhadap KTA yang signifikan (Nursyamsi, 2011). KTA Ultisol berkisar antara 0,80-6,00 $\mathrm{cmol} \mathrm{kg}^{-1}$ sedangkan pada Andisol berkisar antara 1,60$4,00 \mathrm{cmol} \mathrm{kg}{ }^{-1}$. Pada horizon $\mathrm{Bt}_{2}$ Ultisol mempunyai nilai KTA yang lebih tinggi dibandingkan dengan horizon lainnya dengan nilai $6,00 \mathrm{cmol} \mathrm{kg}^{-1}$, demikian juga dengan horizon O pada Andisol dengan nilai 4,00 $\mathrm{cmol} \mathrm{kg}^{-1}$.

\section{C-organik}

C-organik merupakan indikator banyak sedikitnya bahan organik didalam tanah. Pada penelitian ini, kandungan C-organik pada Andisol lebih tinggi dibandingkan Ultisol. Ultisol 
pada lokasi penelitian mengandung C-organik dengan kriteria sangat rendah dengan hanya lapisan O saja yang memiliki kriteria sedang. Sedangkan Andisol memiliki kandungan Corganik dengan kriteria rendah sampai sangat tinggi. Hal ini dikarenakan relatif tingginya bahan amorf alofan pada Andisol yang ditandai dengan tingginya $\mathrm{pH} \mathrm{NaF}$. Mineral alofan dapat membentuk senyawa kompleks dengan bahan organik yang mampu menghalangi senyawa organik dari serangan organisme sehingga menyebabkan kadar C-organik relatif tinggi. Selain itu, bahan organik mempunyai nilai $\mathrm{pH}_{0}$ yang rendah sehingga Andisol mempunyai $\mathrm{pH}_{0}$ yang lebih rendah dibanding Ultisol.

Pola sebaran C-organik semakin menurun seiring dengan menurunnya kedalaman tanah baik pada Ultisol maupun Andisol. Bahan organik mempunyai nilai $\mathrm{pH}_{0}$ yang rendah, sehingga $\mathrm{pH}_{0}$ pada horizon atas Ultisol dan Andisol juga lebih rendah dibandingkan dengan horizon bawahnya. Berdasarkan nilainya, $\mathrm{C}$-organik tertinggi Ultisol terdapat pada horizon $\mathrm{O}$, diikuti horizon $\mathrm{A}, \mathrm{Bt}_{1}$ dan $\mathrm{Bt}_{2}$ dengan masing-masing nilainya yaitu: 2,83\%, 0,87\%, 0,32\% dan $0,08 \%$. Sedangkan urutan nilai tertinggi pada Andisol yaitu horizon A, O, AB dan B dengan masing-masing nilainya yaitu: 7,44\%, 6,11\%, 4,58\% dan 1,87\%.

Kandungan C-organik dalam tanah juga disebabkan oleh pengaruh organisme yang sangat kuat. Organisme merupakan sumber bahan organik bagi tanah selain yang diberikan oleh manusia sehingga kehadirannya sangat menentukan kadar C-organik. Sementara jumlah organisme akan semakin menurun dengan bertambahnya kedalam tanah karena semakin tidak menunjangnya lingkungan bagi kehidupan organisme. Perakaran tanaman yang mati merupakan makanan bagi mikroorganisme tanah yang selanjutnya hasil dekomposisinya akan menambah bahan organik tanah.

Tabel 4. Nilai C-organik, KTA, Al-dd, H-dd, P-Retensi Ultisol dan Andisol

\begin{tabular}{ccccccc}
\hline $\begin{array}{c}\text { Ordo } \\
\text { Tanah }\end{array}$ & $\begin{array}{c}\text { Simbol } \\
\text { Horizon }\end{array}$ & $\begin{array}{c}\text { C-organik } \\
(\%)\end{array}$ & $\begin{array}{c}\text { KTA } \\
\left(\mathrm{cmol} \mathrm{kg}^{-1}\right)\end{array}$ & $\begin{array}{c}\text { Al-dd } \\
\left(\mathrm{cmol} \mathrm{kg}^{-1}\right)\end{array}$ & $\begin{array}{c}\mathrm{H} \text {-dd } \\
\left(\mathrm{cmol} \mathrm{kg}^{-1}\right)\end{array}$ & $\begin{array}{c}\text { P-retensi } \\
(\%)\end{array}$ \\
\hline Ultisol & $\mathrm{O}$ & 2,83 & 0,80 & 0,40 & 0,10 & 40,00 \\
& $\mathrm{~A}$ & 0,87 & 1,60 & 0,61 & 0,10 & 20,00 \\
& $\mathrm{Bt}_{1}$ & 0,32 & 3,20 & tu & 0,52 & 19,20 \\
& $\mathrm{Bt}_{2}$ & 0,08 & 6,00 & tu & 0,31 & 19,52 \\
\hline Andisol & $\mathrm{O}$ & 6,11 & 4,00 & 0,44 & 0,34 & 82,00 \\
& $\mathrm{~A}$ & 7,44 & 2,80 & 0,88 & 0,56 & 98,31 \\
& $\mathrm{AB}$ & 4,58 & 2,40 & tu & 0,56 & 97,47 \\
& $\mathrm{~B}$ & 1,87 & 1,60 & tu & 0,76 & 78,03 \\
\hline
\end{tabular}

6. Kemasaman dapat dipertukarkan (Al-dd dan H-dd)

Berdasarkan hasil penelitian menunjukan bahwa nilai Al-dd dan $\mathrm{H}$-dd pada masing masing horizon Ultisol dan Andisol bervariasi dengan kriteria sangat rendah sampai rendah. Secara kuantitatif, horizon A Ultisol mempunyai kadar Al-dd tertinggi yaitu $0,61 \mathrm{cmol} \mathrm{kg}^{-1}$ diikuti horizon $\mathrm{O}$ dengan nilai $0,40 \mathrm{cmol} \mathrm{kg}{ }^{-1}$, sedangkan pada horizon $\mathrm{Bt}_{1}$ dan $\mathrm{Bt}_{2}$ nilai $\mathrm{Al}-\mathrm{dd}$ tidak terukur. Pada Andisol, Al-dd tertinggi ditemui pada horizon A dengan nilai $0,88 \mathrm{cmol}$ $\mathrm{kg}^{-1}$ diikuti horizon $\mathrm{O}$ dengan nilai $0,44 \mathrm{cmol} \mathrm{kg}^{-1}$, sedangkan pada horizon $\mathrm{AB}$ dan $\mathrm{B}$ tidak terukur. Hasil ini menunjukan bahwa nilai Al-dd semakin menurun (tidak terukur) dengan meningkatnya $\mathrm{pH}$. Hal ini sesuai dengan penelitian Rachim (1989) bahwa $\mathrm{pH}$ dan Al-dd saling mempengaruhi dimana kelarutan $\mathrm{Al}$ dalam tanah dipengaruhi $\mathrm{pH}$ larutan dan $\mathrm{Al}$ yang aktif dapat mempengaruhi $\mathrm{pH}$ pada proses hidrolisis (Tan, 2010). Menurut Arabia (1991), jika $\triangle \mathrm{pH}$ negatif dan Al-dd tinggi menunjukan bahwa tanah mengandung mineral bermuatan permanen.

Adapun kadar $\mathrm{H}$-dd tertinggi Ultisol ditemui pada horizon $\mathrm{Bt}_{1}$ dengan nilai $0,52 \mathrm{cmol}$ $\mathrm{kg}^{-1}$ diikuti horizon $\mathrm{Bt}_{2}$ dengan nilai $0,31 \mathrm{cmol} \mathrm{kg}^{-1}$ serta horizon $\mathrm{O}$ dan $\mathrm{A}$ dengan nilai yang 
sama yaitu $0,10 \mathrm{cmol} \mathrm{kg}^{-1}$. Sedangkan pada Andisol, nilai tertinggi ditemui pada horizon B dengan nilai $0,76 \mathrm{cmol} \mathrm{kg}^{-1}$, diikuti horizon $\mathrm{A}$ dan $\mathrm{AB}$ dengan nilai $0,56 \mathrm{cmol} \mathrm{kg}^{-1}$ dan horizon $\mathrm{O}$ dengan nilai $0,34 \mathrm{cmol} \mathrm{kg}^{-1}$. Kadar $\mathrm{H}$-dd pada kedua jenis tanah berlawanan dengan Al-dd dimana semakin tingginya $\mathrm{H}$-dd akan menyebabkan nilai Al-dd semakin rendah. Sebaliknya, nilai H-dd akan semakin rendah dengan meningkatnya nilai Al-dd.

\section{P-retensi}

Pada penelitian ini diketahui bahwa P-retensi pada Andisol lebih tinggi dibandingkan dengan Ultisol. Pada Andisol, P-retensi tertinggi ditemui pada horizon A, diikuti horizon $\mathrm{AB}$, $\mathrm{O}$ dan B dengan nilainya masing-masing yaitu 98,31\%, 97,47\%, 82,00\% dan 78,03\%. Sedangkan pada Ultisol nilai P-retensi tertinggi yaitu pada horizon O, diikuti horizon A, horizon $\mathrm{Bt}_{2}$, dan horizon $\mathrm{Bt}_{1}$ yang semakin rendah dengan bertambahnya kedalaman tanah dengan nilainya masing-masing yaitu: 40,00\%, 20,00\%, 19,52\% dan 19,20\% (Tabel 3).

Tingginya P-retensi pada Andisol disebakan oleh adanya kandungan alofan yang tinggi pada tanah ini yang mempunyai kemampuan mengikat $\mathrm{P}$. Tingginya alofan pada Andisol ini dicirikan oleh $\mathrm{pH}$ NaF yang juga tinggi. Nilai $\mathrm{pH} \mathrm{NaF}$ pada horizon permukaan sampai bawah berturut turut yaitu 9,85 (O), 10,86 (A), 11,14 (AB) dan 10,23 (B). Sedangkan pada Ultisol, Pretensi lebih disebabkan oleh oksida-oksida $\mathrm{Fe}$ dan $\mathrm{Al}$, sehingga $\mathrm{P}$ menjadi terikat kuat. Hal ini sesuai dengan pendapat Sanchez (1992), yang menyatakan bahwa semakin tinggi oksida Fe dan Al, daya ikat $\mathrm{P}$ pada tanah tersebut semakin kuat.

\section{Tekstur Tanah}

Sifat fisik tanah yang berhubungan dengan muatan tanah pada penelitian ini adalah tekstur tanah terutama kandungan liat, sedangkan kadar air digunakan sebagai faktor koreksi pada beberapa analisis sifat kimia tanah lainnya. Hasil analisis menunjukkan bahwa liat pada Ultisol lebih tinggi dibandingkan dengan Andisol. Urutan horizon dengan liat paling tinggi pada Ultisol yaitu horizon $\mathrm{Bt}_{2}$, horizon $\mathrm{A}$, Horizon $\mathrm{Bt}_{1}$ dan horizon $\mathrm{O}$ dengan masing masingmasing nilainya yaitu 52,35\%, 47,66\%, 37,14\% dan 35,62\%. Sedangkan pada Andisol liat tertinggi ditemui pada horizon $\mathrm{O}$, diikuti horizon $\mathrm{B}$, horizon $\mathrm{AB}$ dan horizon $\mathrm{A}$ dengan masing-masing nilainya yaitu: $12,59 \%, 6,45 \%, 6,08 \%$ dan 5,99\% (Tabel 4).

Menurut Hanafiah (2010), sifat kimiawi tanah sebagian besar berasal dari adanya muatan listrik baik negatif maupun positif yang muncul dari permukaan struktur liat terutama yang koloidal, sehingga tanah tanpa koloid (organik dan anorganik) berarti tidak dapat lagi berfungsi sebagai media tumbuh bagi tanaman (tanah mati). Muatan negatif liat akan bereaksi dengan kation-kation basa seperti $\mathrm{K}^{+}, \mathrm{Ca}^{2+}, \mathrm{Mg}^{2+}, \mathrm{Na}^{+}$dan $\mathrm{NH}_{4}^{+}$, juga dengan $\mathrm{Al}^{3+}, \mathrm{Fe}^{2 / 3+}$, $\mathrm{Cu}^{2+}$ dan $\mathrm{Zn}^{2+}$, sedangkan muatan positif akan bereaksi dengan anion-anion seperti $\mathrm{H}_{2} \mathrm{PO}_{4}^{-}$, $\mathrm{NO}_{3}{ }^{-}, \mathrm{Cl}^{-}$dan $\mathrm{HSO}_{4}^{-}$.

Jenis dan jumlah liat erat hubungannya dengan muatan tanah. Seperti yang telah diuraikan sebelumnya, tanah pada penelitian ini termasuk kedalam liat aktifitas rendah (LAR) dengan muatan variabel. Ultisol dan Andisol ini didominasi oleh mineral liat kaolinit yang bertipe 1:1. Mineral liat ini tidak dapat mengembang dan mengerut serta memiliki luas permukaan spesifik kecil, sehinggga walaupun berkadar liat tinggi tetapi aktifitasnya rendah. 
Tabel 5. Nilai Tekstur Tanah Ultisol dan Andisol

\begin{tabular}{cccccc}
\hline Ordo & & \multicolumn{3}{c}{ Tekstur Tanah } & \\
\cline { 3 - 5 } Tanah & Horizon & Pasir (\%) & Debu (\%) & Liat $(\%)$ & Kelas tekstur \\
\hline \multirow{4}{*}{ Ultisol } & $\mathrm{O}$ & 46,55 & 17,81 & 35,62 & Liat berpasir \\
& $\mathrm{Bt}_{1}$ & 35,00 & 27,85 & 37,14 & Lempung berliat \\
& $\mathrm{Bt}_{2}$ & 21,46 & 26,17 & 52,35 & Liat \\
& $\mathrm{A}$ & 15,25 & 37,07 & 47,66 & Liat \\
\hline \multirow{6}{*}{ Andisol } & $\mathrm{O}$ & 24,43 & 62,97 & 12,59 & Lempung berdebu \\
& $\mathrm{A}$ & 28,14 & 65,86 & 5,99 & Lempung berdebu \\
& $\mathrm{AB}$ & 39,17 & 54,74 & 6,08 & Lempung berdebu \\
& $\mathrm{B}$ & 54,83 & 38,71 & 6,45 & Lempung berpasir \\
\hline
\end{tabular}

\section{Pengelolaan Tanah}

Secara umum kendala tanah kering di Indonesia yaitu kemasaman yang tinggi dan keracunan Al. Hasil analisis pada kedua jenis tanah ini menunjukan $\mathrm{pH}$ yang agak masam sampai netral. Demikian juga dengan nilai yang ditunjukan oleh Al-dd dengan kriteria sangat rendah sampai rendah pada dua horizon teratas sehingga bisa disimpulkan bahwa kedua jenis tanah dalam penelitian ini tidak mengalami kendala kemasaman dan keracunan Al.

Pada Tabel 3 dapat dilihat bahwa kandungan C-organik pada Ultisol lebih rendah dibandingkan Andisol. C-organik pada Ultisol termasuk dalam kriteria rendah sampai sangat rendah sedangkan pada Andisol tergolong sedang sampai sangat tinggi. Peningkatan $\mathrm{pH}_{0}$ pada Andisol disebabkan oleh semakin rendahnya kadar bahan organik dan tingginya alofan pada tanah ini. Demikian juga halnya dengan Ultisol yang mengalami penurunan bahan organik dengan semakin dalamnya lapisan tanah.

Hasil penelitian Martunis et al. (2016) menunjukan bahwa indeks kualitas tanah pada lahan kering di Kabupaten Aceh Besar termasuk pada katagori "sedang" sampai "baik". Salah satu faktor yang sangat menentukan kualitas tanah adalah kandungan bahan organik tanah. Bahan organik dapat mengimmobilisasi bahan-bahan kimia buatan yang memberikan dampak merugikan terhadap pertumbuhan tanaman, membentuk komplek logam-logam berat, serta meningkatkan kapasitas sangga (buffer capacity) tanah (Nurmi, 2003 dalam Arifin, 2011).

Usaha pengelolaan tanah untuk menurunkan $\mathrm{pH}_{0}$ dapat dilakukan dengan penambahan bahan organik ke dalam tanah karena bahan organik mempunyai $\mathrm{pH}_{0}$ rendah. Salah satu langkah yang dapat dilakukan untuk menurunkan $\mathrm{pH}_{0}$ yaitu dengan pemberian kompos. Hal ini dikarenakan kompos merupakan senyawa organik yang berfungsi untuk menetralkan sejumlah muatan positif pada permukaan koloid (Sanchez, 1992). Fiantis (2000) menyatakan bahwa amelioran akan menurunkan $\mathrm{pH}_{0}$ dan meningkatkan KTK. Sejalan dengan itu, penelitian Devnita (2010) menunjukan bahwa pemberian amelioran terak baja, batuan fosfat dan bokashi sekam padi memperlihatkan kecenderungan menurunkan $\mathrm{pH}_{0}$ dan $\mathrm{P}$-retensi tanah walaupun peningkatan KTK tidak dapat dilakukan dalam waktu yang singkat karena daya sangga yang tinggi.

Penelitian Sufardi (1999) memperlihatkan pemberian kompos dan pupuk fosfat dapat menurunkan $\mathrm{pH}_{0}$ serta meningkatkan serapan hara. Hasil penelitian lainnya dikemukakan oleh Hermawan et al. (2014) bahwa pencampuran abu terbang batubara dengan kotoran ayam dapat meningkatkan muatan negatif dan P-tersedia campuran melalui penurunan $\mathrm{pH}_{0}$.

Pengapuran tidak diperlukan pada tanah penelitian ini karena akan meningkatkan $\mathrm{pH}$ sehingga mempengaruhi karakteristik muatan permukaan. Peningkatan $\mathrm{pH}$ akan meningkatkan muatan negatif (KTK) sedangkan penurunan $\mathrm{pH}$ meningkatkan muatan positif (KTA). Ultisol dan Andisol pada lokasi penelitian dicirikan oleh $\mathrm{pH}$ yang berada dalam kriteria agak masam sampai netral dan jumlah Al dapat ditukar yang rendah sehingga 
pengapuran yang berlebihan akan mengakibatkan kekurangan $\mathrm{Mn}$ dan $\mathrm{Zn}$. Jika teknik manajemen bertujuan untuk meningkatkan $\mathrm{pH}$ tanah akan terjadi peningkatan KTK dan penurunan KTA. Peningkatan KTK akan membantu produksi pertanian, akan tetapi penuruan KTA akan mengurangi kemampuan tanah untuk menahan anion khususnya nitrat $\left(\mathrm{NO}_{3}{ }^{-2}\right)$.

\section{KESIMPULAN DAN SARAN}

Hasil penelitian menunjukan bahwa Ultisol dan Andisol di lahan kering Aceh Besar termasuk kedalam liat aktifitas rendah (LAR) yang ditandai dengan KTK efektif $<12 \mathrm{cmol} \mathrm{kg}^{-}$ ${ }^{1}$. Karakteristik muatan pada Ultisol Jantho dan Andisol Saree mempunyai muatan neto negatif dan bermuatan variabel. Penurunan C-organik dengan bertambahnya kedalaman tanah pada Ultisol dan Andisol diikuti oleh penurunan $\mathrm{pH}_{0}$, P-retensi, dan Al-dd. Upaya untuk meningkatkan muatan negatif pada Ultisol dan Andisol yaitu dengan meningkatkan $\mathrm{pH}$ atau menurunkan muatan titik nol tanah melalui pemberian bahan organik atau bahan yang mempunyai $\mathrm{pH}_{0}$ yang rendah seperti kompos, terak baja, batuan fosfat, bokashi sekam padi, dan abu terbang batubara.

\section{DAFTAR PUSTAKA}

Ali, S. dan Sufardi. 1999. Modifikasi Status Muatan Koloid Tanah Ultisol untuk Meningkatkan Kualitas Fisikokimia Tanah dan Produksi Kedelai (Glycine Max (L.) Merriil). Laporan Penelitian. Universitas Syiah Kuala. Banda Aceh.

Arabia, T. 1991. Sifat-Sifat Muatan Tanah Masam Lahan Kering di Daerah Sumatera Barat dan Jawa Barat. Thesis. Institut Pertanian Bogor. Bogor Devnita, Rina. 2010. Tanah Bermuatan Variabel: Sifat Kimia, Mineralogi dan Manajemennya. Paper Universitas Padjajaran. Bandung.

Arifin, Z. 2011. Analisis Indeks Kualitas Tanah Entisol pada Penggunaan Tanah yang Berbeda. Jurnal Agroteksos vol 21(1):58-71.

Devnita, Rina. 2010. Karakteristik Sifat Kimia dan Fisika Tanah Beberapa Andisol di Jawa Barat. Laporan Penelitian Universitas Padjajaran Bandung.

Fiantis, D. 2000. Colloid-Surface Characteristics and Amelioration Problems of Some Volcanic Soils in West Sumatera, Indonesia. Thesis. University Putra Malaysia. Selangor.

Hanafiah, K. A. 2010. Dasar Dasar Ilmu Tanah. PT. Rajagrafindo Persada. Jakarta.

Hermawan, A., Sabaruddin, Marsi, R. Hayati., Warsito. 2014. Perubahan Titik Muatan Nol dan Muatan Negatif Abu Terbang Batubara Akibat Penambahan Kotoran Ayam dan Waktu Inkubasi. J. Agroekoteknologi Vol. 3(4): 191-200.

Martunis, L., Sufardi, dan Muyassir. 2016. Analisis Indeks Kualitas Tanah di Lahan Kering Kabupaten Aceh Besar Provinsi Aceh. J. Budidaya Pertanian Vol. 12(1): 34-40.

Nursyamsi, D. 2011. Mekanisme Pelepasan K Terfiksasi Menjadi Tersedia bagi Pertumbuhan Tanaman pada Tanah-Tanah yang di Dominasi Smekstit. Jurnal Sumberdaya Lahan Vol. 5 (2): 61-74.

Rachim, D. A. 1989. Evaluasi Ketelitian Pemetaan Tanah Detail dan Keragaman Spasial Tanah pada Dua Satuan Peta di Daerah Bogor. Thesis. Institut Pertanian Bogor. Bogor.

Sanchez, P.A. 1992. Sifat dan Pengelolaan Tanah Tropika. Institut Teknologi Bandung. Bandung.

Sembiring, I. S M., Mukhlis, dan Bintang, S. 2013. Perubahan Sifat Kimia Andisol Akibat Pemberian Silikat dan Pupuk P Untuk Meningkatkan Produksi Kentang (Solanum Tuberosum L.). J. Online Agroekoteknologi Vol.1 (4) : 1111-1119. 
Subandi. 2007. Teknologi Produksi dan Strategi Pengembangan Kedelai pada Lahan Kering Masam. Iptek Tanaman Pangan. Vol.2(1):12-25.

Sudaryono. 2009. Tingkat Kesuburan Tanah Ultisol Pada Lahan Pertambangan Batubara Sangatta, Kalimantan Timur. J. Tek. Ling Vol.10(3): 337 - 346.

Sufardi. 1999. Karakteristika Muatan, Sifat Fisikokimia, dan Adsorpsi Fosfat Tanah Serta Hasil Jagung pada Ultisol dengan Muatan Berubah Akibat Pemberian Amelioran dan Pupuk Fosfat. Disertasi Universitas Padjajaran. Bandung.

Sufardi, M. Lukman, dan Muyassir. 2017. Pertukaran Kation pada Beberapa Jenis Tanah di Lahan Kering Kabupaten Aceh Besar Provinsi Aceh (Indonesia). Prosiding Seminar Nasional Pascasarjana (SNP) Unsyiah. Banda Aceh. Hal: 45-53.

Syahputra, E. Fauzi, R. 2015. Karakteristik Sifat Kimia Sub Grup Tanah Ultisol di Beberapa Wilayah Sumatera Utara. J. Agroekoteknologi. Vol.4 (1): 1796-1803.

Tan, K. H. 2010. Principles of Soil Chemistry Fourth Edition. CRC Press Tailor and Francis Group. Boca Raton. London. New York.

Theng, B.K.G. 1980. Soil with variable charge. Department of Scientific and Industrial Research. Soil Bureau, Lower Hutt, New Zealand.

Uehara, G and G. Gillman. 1981. The Mineralogy, Chemistry, Physics Of Tropical Soils With Variabel Charge Clays. Westerview Press. Colorado. 